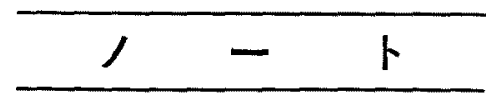

(昭和 46 年 10 月 25 日受理)

\title{
ハロゲン処理ポリプロピレン纎維のらーポテンシャル
}

\author{
大阪女子学園短期大学 麓泉 \\ 大阪府立大学工学部片山明・黒木宣应
}

\section{ZETA-POTENTIAL OF HALOGENATED POLYPROPYLENE FIBERS}

By Izumi Fumoto*, Akira Katayama**, Nobuhiko Kuroki**

* (Osaka Joshigakuen College, Tennoji, Osaka, Japan)

**(Faculty of Engineering, University Osaka Prefecture, Sakai City, Osaka, Japan)

The zeta-potential of fluorinated, chlorinated, brominated and untreated polypropylene fibers (PP) in buffer solutions [at pH 7.0 and 4.1] and in Methylene Blue aqueous solutions [at pH 4.1 and various dye concentrations] was measured at $25^{\circ} \mathrm{C}$ by the streaming potential method. In the buffer solutions, the fluorinated PP showed much more negative zeta-potential than those of chlorinated, brominated and untreated PP. In the basic dye aqueous solutions, the zeta-potential of the fluorinated PP has a tendency to increase positive zeta-potential than the others. Consequently, it was suggested that the fluorinated PP has a large affinity for organic cations, such as Methylene Blue, having the ability to interact with the fiber surface by van der waals and higher negative charge.

(Received October 25, 1971)

\section{1. 緒言}

ポリプロピレン絨維のらーポテンシャルに関してはす “炏須沢”の報告があるが，ハロ ゙゙ン処理ポりプロピレ ン瀻維に関するものは見当らない。

本報では，ポりプロピレン話よびハロダン処理ポリプ

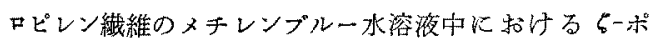
テンシャルを測定した結果について報告する。

\section{2. 試料および実験方法}

\section{1 らーポテンシャルの測定法}

流動電位法を用い, Helmholtz-Smoluchowski ${ }^{2}$ の式 によって算出した。

$$
\zeta=\frac{E}{P} \cdot \frac{4 \pi \eta \lambda}{D}
$$

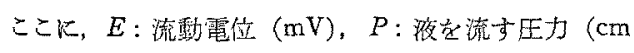

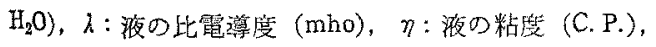
$D:$ 液の誘電率である。

性測定温度 $25^{\circ} \mathrm{C}$ に括ける $0.8949 ， D$ を 80 と し， $E, P, \lambda$ は次に述べる方法によって測定した。

\section{2 流動電位の測定装置}

渡辺らのの用いた方法に準じ，Fig.1 の上うな装犆を

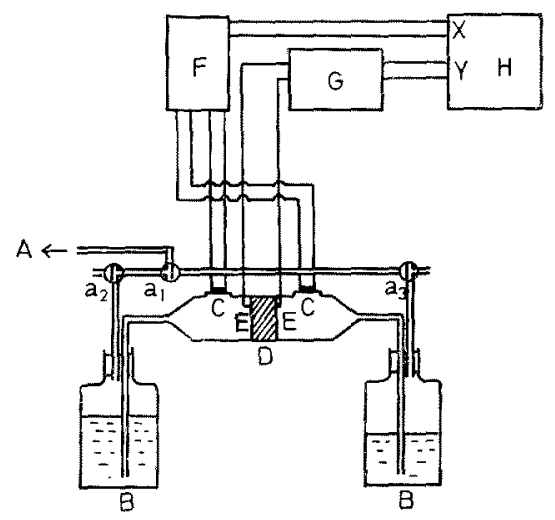

Fig. 1. The measurements of streaming potentials. A : Sucker B : Reservoirs for test solutions $C$ : Beryllium disks with semiconductor strain gauges, D : Cell E : Perforated platinum electrodes, F : I.C.-D.C. Amp. for strain gauges, G: I.C.-D.C. Amp. for streaming potentials. $H: X-Y$ Recorder, $a_{1}, a_{2}, a_{3}$ : Three way cocks 


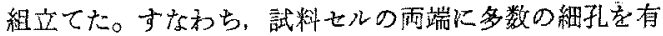
する白金盤を犆き，液を流すことによって無生する電位 差 $E$ は I. C. 直流增幅器飞導いた。セル雨端の間の差压 Pは，半導体ストレインダージを貼りつけた金メッキべ リリウムの薄い円板をセルの両側の流路にとりつけ，水 压の変化によるべリリウム板のひずみをストレインゲー ジと抵抗て構成するブリッジ回路によって電気的出力に

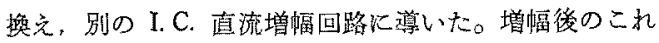
らの出力は $X-Y$ 記録計の $X$ 軸と $Y$ 軸にとり，E/Pが $Y \mid X$ から読みとれるようにした。

液の電気伝導度 $\lambda$ は、コールラウシュ型のホイートス トンブリッジを用いて测定した。

\section{3 試料むよび染料}

ポリプロピレンフィラメント $6 \mathrm{~d}$ (チッ製)をソッ クスレ一の抽出装監を用いてメタノールで洗い, 未処理 試料とした。ハロゲン処理試料は，前報》と同し方法で 気相法によって作製し保存したるので， 八ロダン含有量 る，前報4)と同しく，Schöniger 法6)によって決定した。 流動電位の測定には 1 回につき約 $1 \mathrm{~g}$ の試料壁用い, 瀻 維軸を流動方向になるべくそろえて，せルに充買した。

染料のメチレンブルー（C. I. Basic Blue 9) は市服 特級品を水就よびエタノール溶液から再結晶して使用し た。

\section{4 曘解質溶液の調製}

Britton-Robinson の広域緩衝液（酶酸，リン酸，木 ウ酸の混酸一カセイソーダ系) をらすめ, $1 \times 10^{-6} \sim 10^{-4}$ $\mathrm{mol} / \mathrm{l}$ の濃度籍围のものを用いた。支持塩を加古る場合 は， $\mathrm{KCl}$ そ $1 \times 10^{-4} \mathrm{~mol} / \mathrm{l}$ の割合で添加した。

\section{3. 結果および考察}

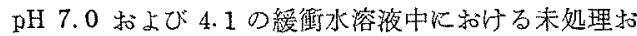
よびハロゲン処理ポリプロピレン瀻維の ルを Table 1 飞示した。

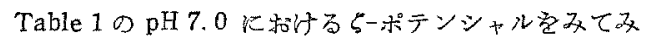
ると，フッ素処理ポリプロピレン瀻維のそれは，未処理 のものに比べて $33 \mathrm{mV} て い と ゙$ 負の値が大となっている
Table 1. $\zeta$-potential of halogenated and untreated $\mathrm{PP}$ in buffer solutions ( $\mathrm{pH} 7.0$ and 4.1 ) at $25^{\circ} \mathrm{C}$.

\begin{tabular}{l|r|r|r}
\hline & $\begin{array}{c}\text { Halogen } \\
\text { content } \\
(\mathrm{mol} \%)\end{array}$ & \multicolumn{2}{|c}{$\zeta(\mathrm{mV})$} \\
\cline { 3 - 4 } & & -64 & -148 \\
\hline Untreated PP & & $\mathrm{pH} 7.0$ \\
Fluorinated PP & 0.05 & $\ldots$ & -172 \\
& 0.10 & -162 & -181 \\
Chlorinated PP & 0.13 & -98 & -146 \\
& 0.18 & -108 & $\ldots$ \\
Brominated PP & 0.35 & -115 & $\ldots$ \\
& 0.002 & -50 & $\ldots$ \\
& 0.06 & -59 & $\ldots$ \\
& 0.09 & -64 & -145 \\
\hline
\end{tabular}

が，塩素呿よび臭素処理ポリプロピレン䋘維のそれは， 末処理のものに比へて羑が認められない。また， $\mathrm{pH}$ を7.0から 4.1 飞変化させを場合のらーポテンシャルは， 表から明らかなように，いずれの蟣維も負の でポテン シャルは低下するが，フッ素処理ポリプロピレン絨維の

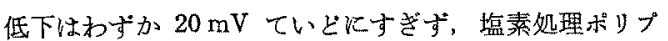
ロピレン瀻維の $50 \mathrm{mV}$ さらに莫素処理特上び未処理ポ リプロピレン瀻維の $80 \mathrm{mV}$ K比べて小さい。このこと は，フッ素処理ポリプロピレン瀻維がプロトンに対して 親和性が小さいことを意味している。

つぎ飞, 種々の涭度の塩基性染料水溶激 $(\mathrm{pH} \mathrm{4.1}$, 支持 塩を含む) 中汇猢る各種ポリプロピレン緎維（ハロゲ

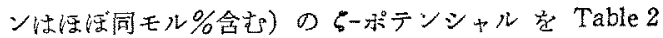
汇示した。この場合, 染料濃度ぜロ炕执いては, Table 1 の $\mathrm{pH} 4.1$ K和けるそれと比較して，いずれの蟣維に 特いても負の ら-ポテンシャルが低下しているが，これ は, 支持塩添加炕よる電気二重層の厚さの压縮に上ると 考交られる。乙かし，溶液に塩基性染料を添加し，关の 漫度を增加すると、フッ素処理ポりプロピレン継維の負 のらーポランシャルは急激に低下乙，染料濃度 $0.24 \times$ $10^{-4} \mathrm{~mol} / l$ 付近飞和いて正の值となり, 染料浀度 $0.88 \times$

Table 2. $\zeta$-potential $(\mathrm{mV})$ of halogenated and untreated PP in Methylene Blue aqueous solutions ( $\mathrm{pH} .4 .1,25^{\circ} \mathrm{C}$ ) at various dye concentrations.

\begin{tabular}{|c|c|c|c|c|c|c|c|c|c|c|c|}
\hline & \multicolumn{11}{|c|}{$\begin{array}{l}\text { Conc. of Methylene Blue }(\mathrm{mol} / \mathrm{l}) \times 10^{4} \\
\left.\text { [Conc. of supporting electrolyte }: 2.27 \times 10^{-4} \mathrm{~mol} / \mathrm{l}\right]\end{array}$} \\
\hline & 0 & 0.04 & 0.08 & 0.16 & 0.24 & 0.32 & 0.40 & 0.48 & 0.88 & 1.68 & 3.28 \\
\hline Untreated PP & -12 & -1 & +6 & +22 & +33 & +43 & +49 & +49 & +48 & +54 & +71 \\
\hline Brominated PP $(0.09 \mathrm{~mol} \% \mathrm{Br})$ & -15 & -5 & +3 & +14 & +23 & +28 & +34 & +38 & +51 & +56 & +73 \\
\hline Chlorinated PP $(0.13 \mathrm{~mol} \% \mathrm{Cl})$ & -82 & -58 & -34 & -11 & +4 & +14 & +22 & +31 & +47 & +64 & +80 \\
\hline Fluorinated PP $(0.10 \mathrm{~mol} \% \mathrm{~F})$ & -146 & $\ldots$ & -43 & -14 & +3 & +14 & +22 & +28 & +55 & +69 & +82 \\
\hline
\end{tabular}


$10^{-4} \mathrm{~mol} / l$ ていど以上に执いては他の織維に比べてやや 大きな正の值を有するようになる。

このような事実は、フッ素処理ポリプロピレン䄉維が 他のハロダン処理瀻維に比べ，電解質溶液中に招いて， プロトンに対しては親和性がと注しいが，メキレンブル 一の上らに分散力がともに働らく可能性の市る有機力子 オンに対しては十分な親和性を有すること意味する。

著者ら ${ }^{6)}$ はさきに, フッ素処理ポリプロピレン織維の 塩基性染料による染色に扮いては，その時間一吸尽率曲 線の結果から、のーポテンシャルが重要な役割を演ずる可 能性のあることを指摘したが，本報の結果はそれを支持 する。のと考觉られる。

\section{文献}

1) 須沢；油化学，15，20（1966)

2) V. Smoluchowski ; Bull. Acad. Sci. \& Cracovie, 182 (1903)

3）渡辺，黑川，西沢；粉体・粉末・治金協会研究発 表（昭 43 等 11 月，浜松）

4）簏 泉; 蟣学誌, 21, 590 (1965), 23, 291 (1967), 26, 382 (1970)

5) W. Schöniger ; Mikrochim. Acta, 1955, 123, 1956, 869

上野；化学の領域，12，942（1958）

6) 簏 景; 紻学誌, 22, 184 (1966) 